表 5 日米の研究揋使用類の売上高比较

\begin{tabular}{|c|c|c|c|c|}
\hline \multirow[t]{2}{*}{$\because$ 国 } & \multicolumn{2}{|c|}{ 日本（昭和39年） } & \multicolumn{2}{|c|}{ フメリカ（昭和36年） } \\
\hline & 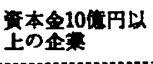 & $\begin{array}{l}\text { 策入䓅術料 } \\
\text { を含士 }\end{array}$ & $\begin{array}{l}\text { 企策负担 } \\
\text { の年 }\end{array}$ & $\begin{array}{l}\text { 登府负担を } \\
\text { 舍む }\end{array}$ \\
\hline 化 & $2.1 \%$ & $2.9 \%$ & $3.6 \%$ & $4.6 \%$ \\
\hline 釷 & 0.9 & 0.9 & 0.7 & 0.7 \\
\hline 境 & 1.0 & 2.5 & 3.0 & 4.4 \\
\hline 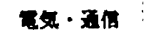 & 2.5 & 3.4 & 3.8 & 10.4 \\
\hline
\end{tabular}

（とくにアメリカ） あおって, 開発段㳻に大部分の研究 費を投資しているのに対し，日本の企莱では基喏，応用 にかなりの部分を投資しており，これが開発効果に大き な影霜を与えていると考えられる。

最近，企菜合垪・大型化の理由の一つとして技術開発 カの強化があげられているが，合併による研究投資額の 絶対頖の增加は潜在的なるのであって，直ちに技術開発 力の強化を意味しないのである。技術開発は，企䍰目的 に合政した研究課題を研究者，研究费を組織的，効率的 に投入して行なわれ，研究管理の果た寸役割はきわめて 大きいるのがある。日本の大企羓において，中央研究所 の研究活動と企業の生産活動の結合が必すしも十分でな いことは度々耳にすることである。また一方，必ずしも 大きくはない企紫において，目的意識の明確な研究活動 によって，数多くの革新的技術が開発されている。主と して技術導入に依存して発展したかが国化学工菜におい ては，領造的技術開発の层統的基盤が脆弱であり，研究 管理も充分なるのとはいえない。外国巨大企莱の技術開 発は優れた研究管理によって支えられていることを忘れ てはならない。

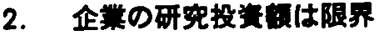

企業の使用額でみる限りわが国の比率はかなり低いこ とがかかる (表 5 参照)。しかし、フメリカの企菜負担と わが国の企業が外国技術迸入のために支払っている技術 料に研究費を加えたるのと比校すると，大きな差は認め られない。

技術䐆入のロイヤリティの大きさが注目されるととも に，わか国企業の研究费支出か限界にきていると考えら れる。

\section{3. 政府负担の增大と点的技街開器}

わが国企業が研究投資類において外国企業と大きな格 差があり, しかる自己負担は売上高比率でみる限り限界 にきていること，さらには研究费の絶対額の不足などか らくろ本格的閏発研究が少ないことを鑑みると，政府㤌 開発段階以降に重点的研究投資を行な弓必要があろう。 また，たとえぱ，重質油の分解（ex. フンモニフ，オレフ ^ンの製造)， C $4 、 C_{3}$ 留分の有効利用 (ex. ポリインフ レン, ブチルゴム, クロロプレ), バラフィンケミカ

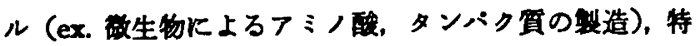
硃ブラスチック（ex.ボリオキシメチレン、ボリイミド フミド，弗化ビニル榯脂)，ファインケミカルズ (ex. 反 応性染料，监光染料，合成樹脂用添加剂)，特殊ガラス (ex. IC 基材ガラス, 磁気ガラス), プロセスェンジニフ リングどの分野に道切な評価によって重点的投資を行 ならことが肝要であると考える。

化学工業の真の親争が，新しい物夏，新しい生産ブロ 七ス、より有利な原料枟换の研究開発にあることを十分 認識して官民一体となった技術開発を行なら必要がある であろう。

\title{
産業技術政策に関する調査報告*
}

田中成 雄 ${ }^{* *}$

1.はしめに

わが国の産莱経済は第二次世界大戦以降世界に類をみ ないにどの高度成辰を遂けてきた。昭和 40 年度の国民 棇生産は 31.3 兆円余であり，また，自䡃車，船舶，鉄

- 昭和 43 年6月3日受理

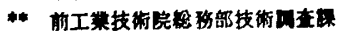

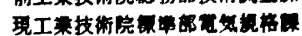

堸，合成樹脂など個々の商品の生産，榆出高においてる 先進諸国に比同し 5 る段階に䔔している。このような高 度成長のすっとす大きな要因は，国民の詝蓄率の高さ，

豊富で良蕒な労㑬力の存在ととすに，技術革新によって 誘発された旺盛な企菜の設備投资であったといわれてい る。しかるこのような設備投资は主として重化学工集分 野に集中して行なわれたため，わが国の産莱粗造は急湤 に重化学工菜化し，近にいたってはこの傾向は蝓出棈 
造にも現われはじめている。

しかしながら、このように発展した重化学工業部門の 実態をみると，そこには否虑すべき問題点が数多く存在 している。すなわちこの部門はいわゆる技術先端産業と いわれる石油化学, 電子, 原子力などの産莱を含み, その 発展の基盤が技術開発力あるい忮術水準依存すると ころが大きい。しかるこの分野ではその技術が日進月歩 で革新されるため技術の陳糜化が急激であり，新技術の 有無が企莱の盛衰を左右するととすに，国家释済の浮沈 にも影辢する性格をるっている。この意味においてわが 国の技術水準がいまだ十分でなく，とくに独創的な技術 開発力が劣っていることは大きな問題と考えられてい る。欧米諸国においては，このような事実認識化基つい てすでに国防，宇宙，原子力などの国家計画を中心に， 電子工業, 機诚工菜, 化学工菜などの先端支術の開発を ナショナル・ブレスティージとし，国自らの責任として 皘極的に推進している。

わが国の産業技術政策についても，今後このような点 に着目して推進する必要があろう。しかしなが，産業 技術政策推進の手段は多種多様であり，現行の個々の政 策についての好果は必すしる满足し得ないるのがある。 さらに各政策手段の有機的連賲をはかることが必要であ ると認識されるにいたった。

工莱技術完では，以上述へたような観点から，わが国 の産業界が当面している問題点を認㖪するととすに，現 行の諸政策および今後必要と考えている諸方策について 企業の意見を把握することを目的として，昨年「産業技 術政策に関するフンケート調查」を実施した。以下，本 調査結果の概要について述へることとする。なお，この

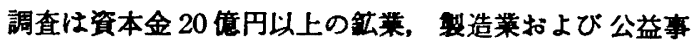

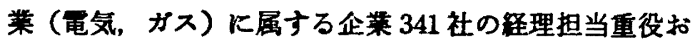
よび技術担当重役（または技衍部門の最高美任者）を対 象とし,昨年 6 月〜7月に実施したるのである。回答率は 企莱べースでは $62 \%$ ，個人べースでは $37 \%$ であった (表 1 参照)。

\section{2. 技街閉発の方針第について}

技術開発の方針として，(1)自社による研究開発，(2外

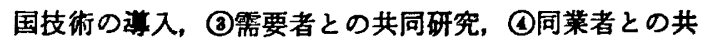
同研究，(5)国立試験研究機関（大学を含を）との共同研 究, (6その他の 6 項目をあげ, 重点度に従って回答者に 順位をつけてるらったが, 表 2 に示すように(1)自社に よる研究開発を 1 位とする回答が何的に多く，1位と した回答中の $94 \%$ を占めている。

美種別にみると，食料品，鉄銅，一般機械，電気機 械，自動車などの業種は(1)((2)の順序で平均型である が，鉱業，航空機，電力，ガスなどの羓種では，(4)「同
表 1 库業技術政策に威するフンケート調查回答状況

\begin{tabular}{|c|c|c|c|c|c|c|c|}
\hline \multicolumn{2}{|c|}{ 莱 } & \multicolumn{2}{|c|}{ 䍜 } & 対象企萧数 & 回答企策数 & $\begin{array}{l}\text { 企莱回答 } \\
\text { 严 }\end{array}$ & 回答者) \\
\hline \multicolumn{4}{|c|}{ 全対象菜盾合計 (平均) } & 341 & 211 & 62 & 254 \\
\hline & 化 & 学 & 品 & 53 & 32 & 60 & 41 \\
\hline 化 & 化 & 学 & 雔 & 5 & 5 & 100 & 6 \\
\hline 学 & 油 & 脂 & 料 & 7 & $\mathbf{5}$ & 71 & 6 \\
\hline$I$ & 医 & 莱 & 品 & 8 & 6 & 75 & 6 \\
\hline & 石 & 油 & 品 & 14 & 8 & 57 & 9 \\
\hline 策 & $\Rightarrow$ & A & 品 & 5 & 2 & 40 & 4 \\
\hline
\end{tabular}

表 2 技術開発の方針

\begin{tabular}{|c|c|c|}
\hline 空問 & 1位とした回签数 & $\begin{array}{l}1 \text { 位 } 4 \text { 点, } 2 \text { 位 } 2 \text { 点 } 3 \text { 位 } \\
1 \text { 点とした场合の誨点 }\end{array}$ \\
\hline (1) & 225 & 927 \\
\hline (2) & 6 & 224 \\
\hline (3) & 3 & 219 \\
\hline (1) & 3 & 109 \\
\hline (B) & 3 & 163 \\
\hline 0 & 0 & 23 \\
\hline
\end{tabular}

表 3 技術成発の内容

\begin{tabular}{|c|c|c|}
\hline 空問。 & 1 位とした回签数 & 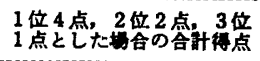 \\
\hline (1) & 105 & 605 \\
\hline (3) & 24 & 358 \\
\hline (2) & 3 & 105 \\
\hline (4) & 97 & 520 \\
\hline (6) & 1 & 30 \\
\hline (0) & 1 & 7 \\
\hline
\end{tabular}

業者との共同研究」が比校的高く評価されて@に次いて いる。また，石油製品，化学製品，化学緎維，非鉄金属な どでは(2)「外国技術導入」を重要視している。食料品, ハルブ・紙，ゴム製品，鉄鋼，金属製品，一般機械，龟 気機械，通信・奄子などの莱種では，(8「需要者との共 同研究」を重要視している。さらに家庭奄器, 精密機械 などの業種は(5)「国立研究機関との共同研究」を高く評 価している。

つぎ技術開発の内容として，(1)現在の製品の品質 · 性能, 設計などの改良, (2現在の生産工程の改善, 合理

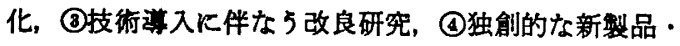
新技術の開発, (6)特定の目的がなく会社全体の技術水準 を向上する基碟 (経常) 研究, (その他の 6 項目につい て前問と同様に重点度に従って回答者に順位をつけても らった結果によると，表了に示すように1位とした項目 は(1)がもっとす多く，回答中 45\%を占めている。次い で多いのが(4)で回答中 $42 \%$ であった。(2は2 位または 3 位に集中している。

業種別にみると、ハルプ・紙, 龟力などの業種は(2) 「生産工程の改善・合理化」が取重点であり, 維維, 化 学製品, 医楽品, ゴム製品, ガラス, 金属製品, 電機 械器具, 家庭奄器, 杭空機, 精密機械などの莱種は, (1) よりも(4)「「独創的な新製品・新技術の閒発」に重点を 
おいている。

\section{3. 国立試験研究機関について}

工業技術院の試験研究機関の活動について関心の度合 いを(1)大いにある, (2ある, (8あまりない, (1)ない, の4 項目にわけて回答を求めた。その結果は (3か $60 \%$ を占 め, (1) $21 \%$ ，(2)20\%，(1)0の順位となった。(3の関心が あまりないと答えたるのに対しては，さらにその理由と して(1)活動の内容がよくかからないから，(2)自社の事業 と関僁がないか，(3自社の事莱と関俰はあるか，工莱 技術院試験研究所は基碳研究に専念しており，生産と直 接に結びつくすのが行なわれていないから，(1)その他の 4 項目に分けて回答を求めた結果によると (1)，(2)（3が それぞれ30\%台で差異がなかった。

業種別にみると，食料品，医薬品，航空機なとにいい ては関係の機関がないため当然関心のない企業が多く， 化学製品，铁鋼，一般機械などの莱種は関心がある企羓 が多い。また，比校的小規模の企莱注と，また研究者数 の少ない企業はど閳心のない企莱が多い。

次に試耠研究設備について@まあまあである，(2)比較 的新しい，(3最新鋭のすのを渞えている，の3区分で回 答を求めた結果によると，(1が $49 \%$ ，(2か; $43 \%$ ，(3か 7\%であって研究設備としては概ね可であるとの回答が 出された。業種別では化学, 鉄鋼などの業種において設 满の近代化に対する満足度が高い。

第 3 問として，国立試検研究機関の行な5べき研究内 容として, (1)基碳研究, (2)工業化研究, (大型ブロジク ト，(1公害，産菜の保安研究，(5その他から3つだけ選 んで欲しい旨の筫問をした結果によると，(1に $26 \%$,

(2) 10\%。，(3に 28\%，に (16\% の回答がなされた。な お(1)の「公害，産莱の保安に開する研究」の希望者は 151 人で回收票数に対しては $60 \%$ 近くが希望している。ま た業種別では食料品, 絆䧴, 化学製品, 電力, ガス, 石 油製品などは、「公害研究の推進」を希望している企業 が多い。化学製品, 鉄銈, 自動車, 龟力, 電気機械器具 は「大型プロジェクトの推進」を強く望んでいる。さら

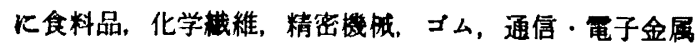
慗品などの莱程では，「工莱化研究」についてその必要 性を認めないためか要望していない。

第 4 問として, 本院試険研究機関の研究成果, 技術指 惎なとにいつて質問した結果，「技術ニュース，所報」 は77\% と大部分の回签者が知っており，「見ていない」 といら莱種は工莱技術院と関伱が浅い食料品，木材・木 製品とか医薬品などの羓種である。「分析，検査，技術 指導」については $71 \%$ かかつて受けている。

工菜技術院武禹研究機関の特故梅を実施したことのあ る企業は $13 \%$ である。
最後に，工莱技術院試験研究機関に対する要望事項と して，(1)産業界の要請に沿った研究をすること，(2)民間

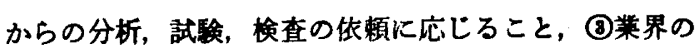
技術指学に重点をおくこと，(19民間との共同研究を皘極 的に行ならこと，(5研究員を交換して相互の協力を強化 すること, 6長期研究計画を明らかにするなど試験研究 活動をPRをすること，(7)その他の7項目をあけ，3つ を挙げてもらった。その結果は「長期計画を明らかにし てPRすること」と「産業界の要請に治った研究をする こと」という要望がとくに強かった。とくに前者につい ては本問回答者の $80 \%$ 近くのすのが要望としてとり上 ゲている。

\section{4. 研究者について}

研究者の採用について(1)全く問題がない，(2)今はよい が今後困難になりそうである，(3困難になってきてい る，の 3 項目をあげて回答を求めた結果，(2)とするのの が 55\% と過半を占めている。業偅別では「全く問題が ない」とい5意見が比較的多いのは，石油製品，一般機 珹，食料品であった。

研究者の待通について(1)一般職員並み，(2)給与上優遇 している，(2)身分上優遇している，(1)その他にわけて回 答を求めた結果，全体の $97 \%$ は一般の職員と特別に 区別していない」としている。

研究者に対して外部から引拔きが行なかれているかど 5かを質問したところ，回答者の $92 \%$ は外部からの引 抜きはあまりなく研究者は注注着していると答えてい る。逆に社外に優秀な研究人材があれば特別の待遇で引 拔くことがあるかとの筫問に対しては，ある $28 \%$ ，な い72\%とい5回答が得られた。

研究者の待迅改善を四るため研究者が会社から受取る 磼赏金などについて所得税の城免措圆を講ずることの是 非について回签を求めた結果, 会社としてす研究意欲の 昂挪に大きなメリットがあるとい5すのと，あまり意味

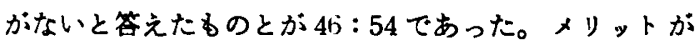
あるとい5すのが比校的多い業種は通信・奄子・電子計 測器，一般機械，金属製品，電力，精密機械などであ り，逆にあまり意味がないと回签したるのが比校的多い

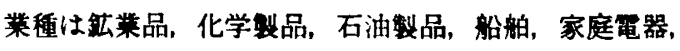
電気機械器具などであった。意味がないとする主な理由

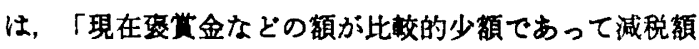
す小さい」といろことであった。

\section{5. 研究管理について}

研究を奻率的に行ない，研究成果をあげるためには， 適切な研究管理が必要である。そこで研究テーマの選 
択, 研究费支出の決定, 研究成果に対する評価などにつ いて質問し，次の結果を得た。

1. 研究テーマの決定，実施にあたって言とすへ き事項

「市場調査を行なってからする」と答えたすのが最も 多く，33\%を占め, 以下,「研究成功度のかなり高いる ののみに限定する」るのが $27 \%$ ，「外国技術動向をみて 判断するるの」が $27 \%$,「その他」が $13 \%$ となった。

\section{2. 研究テーマを最终的に決定する相前}

研究テーマを最終的に決定する組織について，基礎研 究, 汒用研究および工業化研究の段階別に回答を求めた ところ表 4 のとおり回答があった。なお，化学製品は 「すへてての段㳻に対し社長が決定する」というケースが 多かった。

\section{3. 研究要の支出について}

「研究の実態に応して流動的に支出する」すの $30 \%$ ， 「予算を定め，その䈥囲内で研究を行なっている」すの 62\%、「その他」 $8 \%$ であった。

\section{4. 研究管理協会の設立について}

研究管理の手法を開発したり，具体的な研究管理のコ ンサルタントを行ならための研究管理協会の設立につい ての意見を，(1設立しても意義がない，(2)設立の意義は あるが，積極的に参加する意志はない，(3設立されたら 棈極的に参加したいの 3 項目で回答を求めた結果は, (1) $12 \%$ ，(2) 33\%，(255\%で過半数が希望している。しか し(1)(2)の理由としては，「業種別あるいは企業別に業 務内容が巽なり，また秘密情報の流出を避ける意味か ら，個々の企業体自からつくるべぎある」といらのが 共通した考えのよらである。

\section{6. 産業技街大学校の設目について}

国際競争の敏化に対し，研究者，技術者の再教育を目 的とする「産業技術大学校」の設立に対する意見を求め たところ，77\%が必要であるとし，23\%が不要であると している。不要であるとする理由は，(1)屋上屋を架する の思はさけるべきである，(2)各社で実務を通じて教育し た方が効果がある，(3大学院出を採用すれば充分，(4大 学教育の充実が先決，巨大大学の研究室へ出した方が効果 がある，6既存の犝習会でよい，などの意見で教育、再 訓練といったことは大学または自社で行なえばよいとす る考方であった。

\section{7. 工機械類等に係了独刢的な新策品の 性能保証について}

注文生産による重機械類においては，独創的な新製品 を市場化出す場合には、メーカーに括いて充分なテスト
表 4 研究テーマを决定する組織

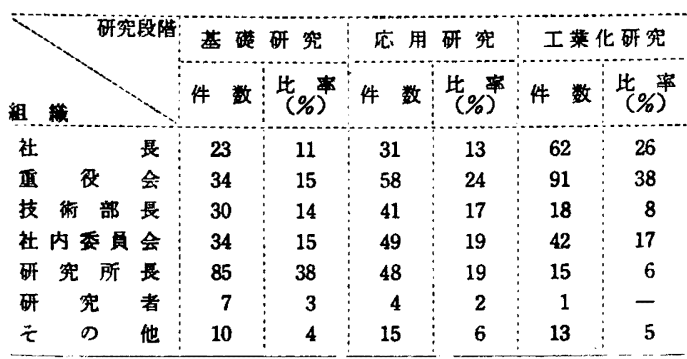

を行なった上で自信ある商品として売出すように努力す ることはメーカーとして当然のことであるが，それでる 使用中に予測しない欠陌が生じ, 品質, 性能面での信頼 性を失なら場合が往々にして起りらる。そこでこの問題 に関する意見を求めたが，問題の特殊性るあって，回答 企業は $41 \%$ の 100 社で，その5ち広義の機械工業(一般 機械，電気機械，輸送機械，精密機械）は $43 \%$ であっ た。

まつ，性能保証について自社の責任において解決して いると答えた企業は回答企業の $90 \%$ を占めている。責 任のとり方としては，「十分な自信をるてるような製品 としてから売出す」69\%，「割引価格でニーザーに試用 を求める」 $22 \%$ 「「ユーザーに対して一定の保証期間を 設ける」46\%，「その他」6\%（2つ以上回答している るのがあるので合計は 100 にならない）であった。

\section{8. 技街振興䨞资について}

新技術企業化に対する日本開発銀行融資制度の周知, 知名度は $82 \%$ に達しているが融資申請は $15 \%$ ，融資実 續は $14 \%$ 程度である。融資実䁇の多いのは化学工業関 係で全体の $40 \%$ を占めており，この制度が設備投資に 対する融資である特徽をしめしている。

融資利率については回答者の $2 / 3$ が現行金利 $(8.2 \%)$ が高いとして括り，開銀の特利の $6.5 \%$ 以下を希望して いるものは $38 \%$ に達している。融資比率については現 行 (30 50\%) でよいとするものが回答数の半ばを占め ていた。しかし 融資比率を $80 \%$ 以上に引上げて欲しい とい5要望も7\%程度あった。手続については，「現行 でよい」 $26 \%$ ，「煩雑である」74\%であり，秘密保持に ついては，「現行でよい」39\%，「改善の要がある」61\% の回答を得た。以上要約すれば，手続は煩雑であり，秘 密保持についてる不安があるということになる。しかし ながら，融資制度について今後の利用の意向を質問した 結果によると，「できるだけ利用したい」が71\%、「利用 するつるりはない」が $29 \%$ であり，利用の希望は多い。 


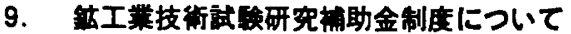

民間の技術開発助成を目的として, 昭和 25 年から 本 制度が実施されているが，知名度については 94\% に達 している。交付を受けたるのは 57\%であり，これる業 種別にみると，化学工羓 $69 \%$ ，鉄鋼業 $78 \%$ ，非鉄金属 $77 \%$ ，電子工羍 $100 \%$ ，家庭電器 $100 \%$ ，電気機械器具 64\%，航空機工業 100\%であった。

補助金が企羓の莱簣に与えた效果については，「大い に責献した」が37\%、「それ汪どですないが $63 \%$ で点 数はからい。しかし，回答者の 70\%は今後補助金を利 用したいとしている。

補助金制度の批判としては， 1 件当り補助金額の增加 (26\%), 補助率の向上 $(17 \%)$, 事移手続，会計監査の 简素化 $(17 \%)$ 等について意見が多い。

試硢研究费の蜃算制度については期待するるのが77 \%に達しており，研究段階別にみると工莱化研究段階か $58 \%$ とっとも多かった。この傾向仕化学工莱，鉄銓業 に著るしい。

\section{0. 技街振興のための税制について}

自己研究開発の画期的な新製品，新技術により生した 所得に対し，法人群を減免する制度の㓣設について意見 を求めたところ，減群に結びっくこのような制度を設け ることは良いと思うか，実施しても，新製品の認定が简 単でないため効果がそしいとする意見が多かった。

国内技術湓渡所得に対する法人祝の诚免制度に関連し て，国内交流を阻害する要因があると思うかどうかにつ いて栄問したところ，回答の $68 \%$ は阻害要因がないと している。阻宫要因としては，「競争意識か強すぎるた め自社で技術を独占しなければならない」とするすのが ほとんどであった。

以上を概钼すると，技術振興のための税制に対する各 企莱の䈍度は何らかの措量を呈んではいるがあまり程極 的でないといえる。

\section{1. 瓷本自由化に伴う技街水滥の向上策について}

ます外国企莱とくらへて技術水渒が低いか否かの筫問 に対しては，両者はほ半ばしている。水㲚が低いと答え たるのが多い業種は，一段機城、奄子機器，電気機器，家 庭䉓器, 自動車, 船絈, 杭空機, 而力等であり,ない

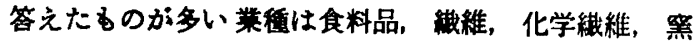
莱，金属，ガス等であった。

具体的に爸っている技術としては，原子力利用，宇宙

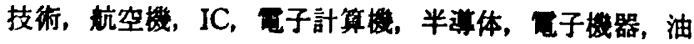

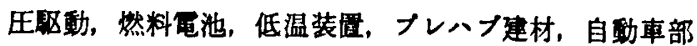

品, 船舶機器, 石油精製機器, 送配電機器, 紙加工, さ く井，数值制御等が挙げられている。このよ5K劣って いる技術は開発により追いつくか，との貝問に対しては 93\%のものが追いつくとしている。その際政府の助成を 必要とするか，との質問に対しては，必要とすると答え たすのが $83 \%$ であった。このような技術テーマに対す る高額，高率補助金については，86\%が利用すると答え ている。

\section{2. 共同研究について}

国際的に技術競争が潄化している現在，限られた研究 投资力を効率的に活用するためには，民間企業間の共同 研究を推進する必要があると思われるが，これについて の企業の考え方を要約すると，次のとおりである。

共同研究については漠然とは良いかすしれないと考え ているか，必要がないかきり稜極的に共同研究を実施し よ5とは思っていない。その理由としては，(1自社の秘 密が他社にもれる，(2技術扣よびそれによる利潤を独占 したい，(2)共存共栄は難しい，(1)他社が信用できない， (5チームワークがわるい，6研究速度がおそい，などが 挙けられている。

\section{3. 技街情報活動について}

回答結果を要約すると，各企業は科学技術情報センタ 一の䝯料を含めて，文献，瓷料から情報を入手している か，海外情報についてはなお不十分であるとの意見が大 勢を占めている。一方，情報検索のための䉓子計算機が 大部分の企莱にとり入れられることは，不可能に近く， 经清的であないので，現存の情報提供機関の整满，执充 が望主れている。

\section{むす ひ}

以上，産業技術政策に関するフンタート調査の結果を 述へたが，纸数の関保るあり十分な解析を試みることが できなかったことを御諒承願いたい。

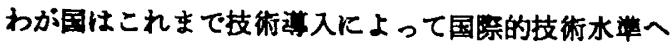

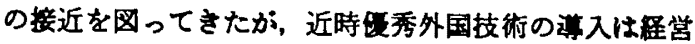
动等の条件の加重により一段ときびしくなってきた。 とくに戦後はじめてわが国経済を震憾させている資本取 引の自由化を迎えたわか国においては，その国際的地位 を高めるためには，産業の自主珄を保持しつつ，産業椣 造の改善，独自的技術の開発力の培莀を図ることが重要 であると認誡されている。最後に技術政策网网する政府 の基本的な施策を揭げて簕をおくこととする。

(1) 研究投資類は，現在国民所得の約 $1.8 \%$ である 
が、これを先進諸国の最低水準である $2.5 \%$ 程度に引き 上げること。

(2) 国の資金負担割合を現在の 3 割から少くとも全体 の過半にまで增大させること。その際には欧米との技術 格差がいちちるしい分野拉よび先端的技術分野において は，国が技術開発の主体となる体制を確立すること。

(3) 技術開発の大規模化，複雑化等に対処して，民間 の研究投資の大型化，効率化を図るため，企業合併等産 業体制の整備を促進すること。

(1) 国の試硂研究の実施，民間企業等に対する研究助 成等に当っては，資金の重点的眠分に努めるとともに，
研究管理を充実し，研究効率の向上を図ること。なお， 技術開発のための重複を避けるため，特許の審查，審判 の促進を図り，特許の早期公開，特許情報，技術情報の 提供等情報サービス活動を強化すること。

(b) 技術開発の終局段階である新技術の企業化に必要 な資金の融資制度を整備し，国産技術の産業への定着を 困るほか，技術開発意欲をおこすための前提となる新製 品，新技術の需要を確保するための施策を促進するこ と。

(6) 頭脳流出を防止し，有用な研究人材を確保するた め, 研究者の待遇改善等の措置を粨ずること。

\section{資本の自由化と大型プロジェクト*}

\section{1. 大型プロジェクト琶生の背最}

昭和 35 年 IMF 8 年国になり貿易の自由化に踏切った わが国は続いて昭和 39 年K OECD (洋済協力開発機構) に加入を認められ本格的開放泽済体制に入った。これに とるない先進国の義務として日本に資本自由化を求める 声が国際的に高まりわが国も前向の方向で資本自由化の 具体的スケシュールを検討してきた。化学工羓について る昨年あたりから資本の自由化の中で特に問題の大きい 技術道入の自由化についてその影䉕を調査し，摩擦をで きるだけ少なく自由化を進めるいく検討が関俰方面で重

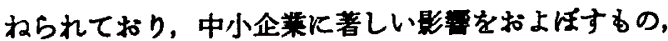
その業界が導入技術により独占的に支配されるような特 例を除き，原則的に技術導入は早晚自由化される方向に ある。

戦後の日本の産羓の発展にとって外国からの導入技術 の果した役割は大きいるのがあり石油化学工業の例を見

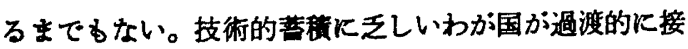
木にたとえられるような技術の䅡上なく完成した技術を 買って来て間に合せるといった手段をとったのは己むを 得ないことであったが，贯近ではこの根無草の慗害が目 立ってきている。技術導入条件の悪化す注目されるよう

* 昭和 43 年 4 月 30 日受理

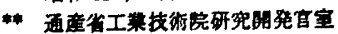

になっており，技術の買い取りが難しくなり，50\%以上 の資本参加による実質的な企業支配や交換できる優れた 技術を代傥に求められる例や，输出市場について铰しい 制限を設け市場確保の面で不利な条件を強いられること が多くなっている。

貿易自由化の場合榆入飞必要な外貨割当制度を廃止し たたけで関税率る操作したり，緊急関税制度を適用して 外国製品のダンピングよりかが国の産業を䇆した場合 は一時的に高率な関税をかけて保謨したり，発展の途上 にある幼稚産業に対しては関税割当制度を暗用して榆入 且をおさえたりすることができる。これに対し資本自由 化の場合は丸裸で何ら保讙のない全く対等の立場で欧米 諸国との競争の場にさらされることになる。対等の立場 とは言光技術萫積の焦弱さ，金利中資金面の不利，研究 開発に対する政府の負担する割合の低さ等を考えると， 欧米諸国に比べ不利な条件下で対等の競争を強いられる と言った方が適当である。

通商産業省で従来からとってきた工莱技術振興のため の施策としては，重要な試硂研究に対する補助金の交

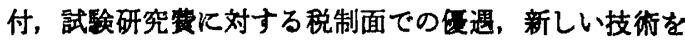

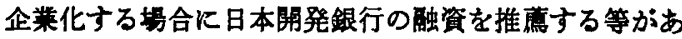
るが，研究费に対する補助額が低くて実質的には大部分 が民間負担によるるのであったり，政府予算の単年度主 義にしばられて，2 年以上の長期計画によって研究を進 